DOI: 10.34185/1991-7848.itmm.2020.01.016

\title{
ВІЗУЛЬНЕ МОДЕЛЮВАННЯ КЕРУВАННЯ ДАТЧИКАМИ ОЗОНУ
}

Кісельов Є.М., к.т.н., доц., Алексієвський Д.Г., к.т.н., доц., Туришев К.О.

\section{Запорізький національний університет}

Ключові слова: АДАПТИВНА КОРЕКЦІЯ, ПОХИБКА, ЧАС, ВИМІРЮВАННЯ, КОРЕГУВАННЯ.

Сьогодні одним 3 перспективних напрямів інтенсифікації металургійних виробництва та підвищення ефективності спалювання вугілля на ТЕЦ $€$ використання озону в суміші 3 киснем [1]. Це потребує використання озонаторних станцій 3 малим енергоспоживання та точним контролем продуктивності генерації. 3 цією метою було розроблено компактний пристрій [2] $з$ виробленням озону кількістю 10 г/год., із споживаною електричною потужністю 30 Вт, що $є$ оптимальним для дезінфекції i/або дезодорації обладнання, виробничих приміщень або резервуарів.

Для визначення концентрації вмісту озону у воді традиційним $\epsilon$ використання електрометричних і колориметричних методів вимірювань. Датчики озону, побудовані на основі таких принципів, мають обмежене застосування в промислових умовах, що пов'язано 3 забрудненням i деградацією робочих поверхонь і як слід - з необхідністю періодичної заміни або калібрування чутливих елементів. Найбільш ефективним засобом підвищення ступеня точності таких пристроїв $є$ корекція похибок. Вимогам зі швидкодії i точності визначення концентрації озону відповідають вимірювальні системи, розроблені на принципах адаптивних систем керування, що допускають зміни своїх параметрів і структури при зміні характеристик об'єкта і умов роботи. Тому актуальним $є$ дослідження адаптивної корекції датчиків випромінювання системи визначення концентрації озону.

Систему визначення концентрації озону, згідно другому методу Ляпунова, можливо відобразити на рівні різних ступенів докладності. Якщо брати до уваги перший порядок точності вимірювальних величин, то адаптивна система буде мати крок зміни вхідної величини, що дорівнює 5 і структуру системи адаптивної корекції можливо представити у середовищі VisSim, як показано на рис. 1. Встановлено, що під дією дестабілізуючого впливу, що відбувається у момент часу $t=1$ похибка вимірювальної величини стрімко зростає. Це 
International scientific and technical conference Information Technologies in Metallurgy and Machine building - ITMM 2020

призводить до відповідного збільшення величини регулюючого впливу 3 метою компенсації негативного впливу. Т. ч. адаптивний корегуючий пристрій протягом часу $t=27$ мс повністю стабілізує сигнал на виході вимірювальної системи і мінімізує величину похибки котра дорівнює 0,2.

Якщо врахувати другий порядок точності вимірювальних величин, то структуру системи адаптивної корекції другого порядку можливо представити у середовищі VisSim як показано на рис. 2.

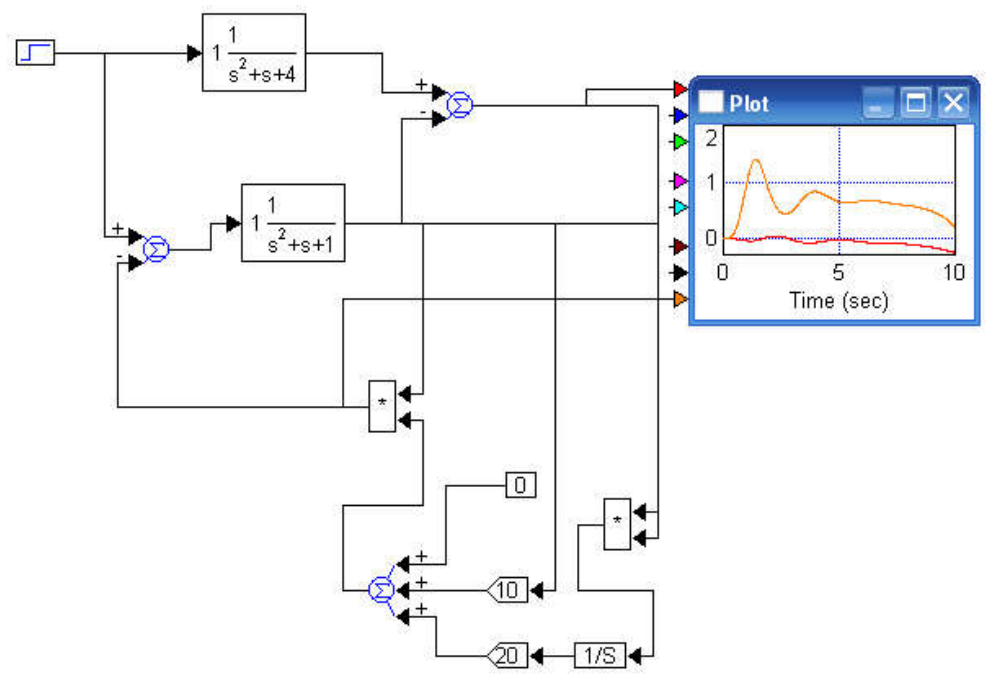

Рисунок 1 - Структура системи адаптивної корекції першого порядку

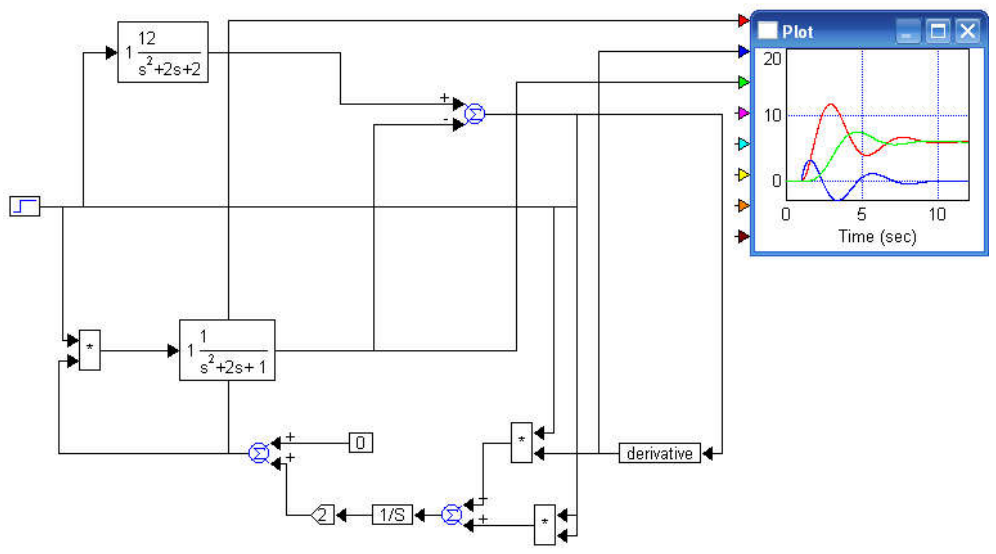

Рисунок 2 - Структура системи адаптивної корекції другого порядку

Проведені модельні дослідження дозволили встановити, що при оптимальних параметрах системи адаптивної корекції другого порядку час встановлення дорівнює 16 мкс., амплітуда похибки - 1.6.

На основі модифікованої моделі адаптивної корекції було розроблено схему електричну принципову блоку адаптивної корекції. Основою розробленого блоку $є$ мікроконтролер ATmega328, що реалізує алгоритм адаптивного керування. Моделювання блоку адаптивного керування 
датчиками концентрації озону проводилось у середовищі Proteus, a макетування - за допомогою налагоджувальної платформи Arduino. Проведені дослідження підтверджують працездатність розробленого блоку і програмного забезпечення, а також дозволили встановити оптимальний розмір програмного коду.

\section{Література}

1. Blondeau R. (ed.). Metallurgy and mechanics of welding: processes and industrial applications. - John Wiley \& Sons, 2013. - 512 p.

2. Екологічні та технічні перспективи застосування кисню й озону / Т. В. Критська, К. О. Туришев, А. В. Таранець // Металургія. - 2016. - Вип. 2. - С. 119-122.

\section{VISUAL CONTROL MODELING OZONE SENSOR}

Kiselov Yehor, Aleksiievskyi Dmytro, Turyshev Kostiantyn

Abstract: A visual mathematical model of the adaptive correction system based on the use of the modified Lyapunov second method to control the sensors of the ozone station was created. Studies of the developed model have shown that the installation time is $16 \mu \mathrm{s}$ and the maximum error amplitude is 1.6. The adaptive correction system has an optimum operating mode, with increased setup time and maximum error amplitude. It is shown that the maximum deviation of the control signal is $160 \mathrm{mV}$ and within $27 \mathrm{~ms}$ the system completely compensates for the interference and stabilizes the measurement error at the level of $0.2 \%$. Studies of the developed unit and software validate the performance and showed that the size of the software code is $18.7 \mathrm{kB}$, and the speed is at the level of $14 \mathrm{~ms}$.

Keywords: ADAPTIVE CORRECTION, ERROR, TIME, MEASUREMENT, CORRECTIONS.

\section{References}

1. Blondeau R. (ed.). Metallurgy and mechanics of welding: processes and industrial applications. - John Wiley \& Sons, 2013. - 512 p.

2. Ekolohichni ta tekhnichni perspektyvy zastosuvannia kysniu y ozonu / T. V. Krytska, K. O. Turyshev, A. V. Taranets // Metalurhiia. - 2016. - Vyp. 2. - S. 119-122. 